\title{
Deconstructing the Bully and Victim Dichotomy
}

\author{
Process Drama in the Japanese EFL University Classroom
}

\section{Eucharia Donnery}

\begin{abstract}
Although steps have been taken to address the issue of ijime or bullying, it remains is a serious social problem within the Japanese educational system. The main focus of this pilot study was to ascertain how beneficial process drama could be in developing oral communicative skills in the target language of English as well as to build social awareness through the deconstruction of the bully and victim dichotomy. Process drama in language acquisition is unique in its aim to fuse language learning and personal development. The average Japanese university student has had six years of compulsory English education, with an emphasis on grammar-translation and accuracy. This means that, while the average student excels at translation and test-taking, s/he has had little experience with communicative English and has no sense of ownership of the language. Because of this lack of oral communicative skills, process drama is an ideal means to build the bridge to communicative competence. This paper is part of a larger tri-semester process drama project and the data accumulated from all three will be used as evidence in a final $\mathrm{PhD}$ dissertation.
\end{abstract}

\section{Introduction}

This pilot project took place in the newly created Faculty of Human Welfare Studies (HWS) at Kwansei Gakuin University (KGU). The main focus of this pilot project was two-fold; firstly, to what extent has the issue of bullying has impinged on the lives of first year university students in a Japanese Christian university, and secondly to deconstruct the bully-victim dichotomy for the purpose of mutual understanding.

\section{Literature Review}

The question as to the prevalence and consequences of bullying led to the pioneering work of Swedish researcher Dan Olweus in the 1970's, which had a considerable impact on educational policies in countries such as Japan. His 
research, sound within a Swedish cultural context, had a profound influence on Yohji Morita who applied it to the Japanese situation. Morita's (1994: 311) research data focused on the culturally-specific nature of bullying in Japan, called ijime, which he defined as "a type of aggressive behavior by which someone holds the dominant position in a group interaction process, by intentional or collective acts, causes mental and/ or physical suffering to another within the group." His work has had a direct impact on the Japanese educational system at the governmental level while his collaborative study with Olweus et. al. (1999) has earned him international recognition and demonstrated the differences between bullying in Japan and elsewhere.

\subsection{Rural to Urban: The Case of Kansai}

The chasm between rural idyll and urban bustle is a particularly wide one in Japan. In rural Japan, where the spirit of the agrarian class prevails, there are many signs extolling all members of the community to "smile and greet each other with open hearts." In the urban setting, however, anti-bullying posters are widespread (See Appendix I). In the Kansai (Kyoto-Osaka-Kobe) region, ijime seemed to be less prevalent and awareness of this social problem seemed to be higher.

With respect to bullying within the Kansai area, there is an additional component worth knowing in order to understand attitudes to bullying within this region. Since feudal times, Japan had officially had a four-tier class system: the warrior or samurai, the farmer or hyakushou, the artisan or shokunin and the merchant or chonin. However, this system excludes those above the rank of the samurai, the military commander or shogun and the gentry or daimyo classes, and the rank below the merchant class, the ethnic minorities of the Ainu in the north, the Ryukyu people in the south, and the Buraku people in central and western Japan. The Buraku people, in particular, were akin to the Dalit or Untouchables of India, involved in the leather trade and in the burial of the dead.

This four-tier system was in upheaval during the 250-year period of national isolation and, when American ships forced open the doors of Japan in 1853, it collapsed completely. In the aftermath of World War II, blatant discrimination prevented success within the employment market and the only sector willing to provide employment was that which had been set up by the Americans education. Within the Kansai region, there seems to be a higher awareness of discrimination faced by the Buraku people from within the education sector as a whole There is an increasing awareness on the part of educators and parents, as well as students themselves, of the darker issues surrounding bullying and the emerging problem of cyber-bullying. 


\subsection{Present Day EFL and JFL}

While many aspects of drama-based pedagogy have been exploited for second language acquisition in the Japanese foreign language (J.F.L.) classroom both in Japan and elsewhere, the benefits that process drama can offer to the English foreign language class are still relatively unknown. Within the Japanese as a Foreign Language classroom, drama-based pedagogy is actively used in Tokyo's Waseda University by Professor Kawaguchi, at the University of Victoria in Canada by Professors Noro, Poulton and Hewgill at the University of Santa Cruz, California by Professor Sakaii and at the University of Kentucky by Professor Sajiki, In contrast to these progressive attitudes to drama-based pedagogy in the JFL class, there seems to be a reluctance to use drama-based pedagogy to develop various skills in the target language of English within English foreign language classes at the university level in Japan. Despite this rather hesitant attitude towards drama-based pedagogy in English language education, examples of drama-based pedagogy in the English language curriculum do come to mind. In 2007, Professor Araki-Metcalfe left the campus of Kyushu Jogakuin University in order to work with primary school children of the Yokote Elementary School, Fukuoka. At university level, Mr. Charles Kowalski uses storytelling and role-play, while Dr.Yuka Kusanagi uses the traditional storytelling technique of "gundoku," a form of reading-in-round, as a stepping stone to dramatic realization of the text. It is apparent that while there is an awareness of the benefits of drama-based pedagogy and there are stories of success within the EFL community in Japan, unfortunately, the drama-based EFL community is still a small group. To date there is a distinct lack of academic materials published by the few practitioners who do include drama pedagogy in their curricula.

\subsection{DIE and DLA}

The main overlap between Drama-in-Education (DIE) and Drama-in-LanguageAcquisition (DLA) occurs on the value placed on experience learning. Both also provide a point of access for engagement with and exploration of social issues and there is great emphasis placed on questions, rather than answers. However, whereas the proponents of DIE have tended to be primary school educators of the Language 1(L1) learner, DLA has much to offer the Language 2 (L2) learner of all ages, not only in terms of language learning but also social learning. In essence, drama in language acquisition offers the learner a chance to educate, entertain and engage with a particular social issue while losing cognizance that this is being done through the target language of English.

Process drama relies on finding an angle that is relevant to the students within their field of knowledge and experience and has a direct resonance in their lives. Rather than moving in a predictable and linear narrative, both students and teacher move in and out of roles, allowing time for further research online or self-reflection. Although it is the teacher who sets the scene for the class-in-role, it is the students who volunteer their roles within the scene. It is necessary to create a safe environment in which to speak English without 
ridicule, both between teacher and students, as well as between the students themselves in order to foster the idea of a shared responsibility for the learning process. As Tsuchida and Lewis (1998: 199) point out that while in many Western educational systems success is rewarded, in the Japanese elementary school system "participation is the reward." Likewise, the aim of process drama is to empower students and allow them to assign and be assigned meaningful tasks by fellow students. Thus, the roles that have been chosen by individual students as part of a group negotiation and this has a greater motivational impact than if the role had been designated by the teacher. Also, most teachers, by virtue of age, social standing, and, in the case of language acquisition in particular, nationality, are outside of the student group and therefore not privy to the circumstances that provide resonance for the students. The teacher can, however, add dramatic tension by the setting up a situation which needs an urgent response, by the construction of an unexpected conflict and by giving or withholding important information. Through process drama, students can engage with pre-existing knowledge of the subject material, bullying in this case, and this can pave the way towards a deeper understanding from multiple perspectives and through the L2 of English.

\section{Teaching Context}

\subsection{Historical Perspectives: Kwansei Gakuin University (KGU)}

As mentioned previously, the official class system was in upheaval throughout the 250 years of isolation of Japan and collapsed with the arrival of the American ships in 1853. When Japan saw how far it was behind America and the rest of the world technologically and intellectually, it flung its doors open to new ideas and religions. When American missionary Reverend Walter Russell Lambert opened Kwansei Gakuin as a seminary for the Methodist faith in 1889, it allowed Christians in the Western region of Kansai to practice their religious beliefs openly and without fear of execution which had been a very real threat during the years of national isolation. In harmony with the school's historical mission, the Faculty of Human Welfare Studies was created in 2008 and was divided into three departments: Social Welfare, Social Development and Human Sciences.

\subsection{Course Overview}

In keeping with HWS's ethos of compassion, comprehensiveness and competence s the process drama course was designed to facilitate the students' understanding and compassion through the communicative competent use of English. This section of the course ran from the eighth week to the fourteenth week of the fall semester 2008 and focused on the social issue of bullying (see Appendix II). This section of the course was designed to utilize the pre-existing skills of debate, speech, and presentation and to permit students to negotiate their own 
understanding of bullying through role-play. In this way, it would allow the students to shift away from English-as-target, towards English as the vehicle for meaningful exchange. As mentioned previously in the introduction, suicide brought about by bullying is a serious and widespread problem in Japan, ranging from the elementary school student to the aging employee. The course was task-based in which the students were guided to examine the issues surrounding bullying and develop compassion for both the perpetrator and the victim.

As part of the first week orientation for the students of Faculty of Human Welfare Studies, there were lectures outlining the university's zero-tolerance approach to ijime. For any student with such a problem, the Student Support Center offered a multi-faceted approach to the problem of bullying involving the three relevant groups - the parents, the students and the teachers - as well as legal aid. Before this project began, students were reminded of this zero-tolerance of bullying and were given directions to the Student Support Center.

\section{The Phases of the Process Drama Pilot Project}

\subsection{Process Drama and Human Welfare Studies (HWS)}

According to Bowell and Heap (2001: 10), there are six principles in the paradigm of the planning process: theme or learning area, context, roles, frame, sign and strategies. Within the process of preparation, there is a shape and a sense of where the process drama may go, however, because it is learner-driven and unpredictable, the only way that the teacher can make the prerequisite leap of faith is through paying particular attention to the process of preparation. The psycho-social aspects of bullying were explored in the safe environment of the classroom and online, from how bullying comes into existence, via the perspectives of both the perpetrators and the victims to the more practical matter of how bullying can be resolved. This topic allowed for a wide variety of vocal and physical expression around the emotions that are not usually represented in the traditionally teacher-led EFL classroom. As the students were from the faculty of HWS and aspire to being social workers, social enterprise developers, and teachers of the future, the issue of bullying seemed relevant to all the core subject areas.

Because the emphasis of HWS was directed towards social issues in these areas, the average student was quite motivated to explore social issues through research and analysis. Therefore, it was with this knowledge that the process drama project was in keeping with the students' core studies.

As stated earlier, these first year students were in the unique position of being the first cohorts in the newly created Faculty of Human Welfare Studies. However, there were both advantages and disadvantages in being the first students on all courses in the faculty: they could actively negotiate their own curricula but also lacked the support of mentors. As an elective the 
English Communication course is usually taken by students who are reasonably motivated and fairly enthusiastic about learning the target language of English. The classes were streamed into advanced, intermediate and elementary and the two classes that were to take part in the project would be from the advanced and elementary levels. Thus, active participation was expected.

\subsection{And ... Action: Starting the Project}

On the first day in this section of the course, students negotiated what parts of the process drama were open and public, and which areas were to be personal between the student and teacher. The majority of students agreed that much of the practical and online aspects of the course should be in the public domain, while the writing-in-role diaries were to be in direct communication with the teacher.

Starting from the point that most people, irrespective of nationality, have times when they need to ask for help in some way, the first class opened with a role play that involved a dilemma, whereby NOT asking for help had compromised the grade of the group (see Appendix III). Students then brainstormed the difficulties in asking for help and devised group role plays in which they created a scene in which a relatively simple problem was resolved through actively asking for help. Students were asked to write anonymously about three problems they were currently experiencing and, for the next few weeks, these problems were posted on the discussion board in the class' Google Group for other students to offer advice (see Appendix IV).

The next class opened with an announcement-in-role of a clip taken from an Australian radio transcript of how a Japanese high school student was threatening the Japanese government by announcing his intention to commit suicide should the government not take immediate steps to stop the problem of bullying across the nation of Japan. In a move to facilitate deeper understanding of and empathy towards those who had found themselves to be in the position of the perpetrator, victim or bystander in the issue of bullying and its impact on society, this was played as an audio announcement, in which the teacher and a colleague recorded a tape-script of the actual news broadcast from ABC in Australia. Following this announcement, printouts of the anonymous suicide letter from the high school student to the Japanese Minister of Education were distributed to all members of the class. ${ }^{1}$ Finally, to offer the frame for the bullying process drama project, the president-in-role sent a letter to the students in their role as the student council, asking for their help in mounting an anti-bullying campaign.

As the project was a pilot, the context of the process drama was that of an imagined case of bullying at KGU that had led to a suicide and the president had asked the class-in-role as student council by letter, to come up with a campaign to outline the nature of bullying with recommendations about how it could be stopped. These recommendations were submitted as both a written

\footnotetext{
${ }^{1}$ See http://www.abc.net.au/am/content/2006/s1786262.htm.
} 
report and an oral presentation at the end of the semester. Since this was an extremely delicate topic, especially given the high numbers of students who had experienced bullying firsthand (see Appendix VI), as well as the nature of the learner-centered class, sensitivity was of utmost importance.

The letter from the president-in-role was affixed to the blackboard throughout the project (see Appendix V). A survey as to the prevalence of bullying in the students' lives both past and present was then distributed and collected (see Appendix VI). As homework for the following class, students developed a role play in which bullying occurred. The following class opened with video clips about bullying. After performing their role plays to the class the following day, the students formed an online group in Google Groups as a place to post information about bullying and offer advice with respect to the secret worries of the class. Then the students researched online about how extensive the problem of bullying in Japan really was and, in groups, they brainstormed about bullying, outlining when, where, and how bullying occurs.

\subsection{And ... Action: Moving through the Project}

The students were randomly assigned into groups of four and asked to create a tableau of bullying. While in pose, students spontaneously added one line of dialogue before breaking to create a role play of the five minutes preceding and anteceding this tableau. This was the first role play which became known to the class as the "Victim Role Play," and was frequently referred to as the basis for the project.

The next day opened with a true-life anecdote about an ill-tempered horse. This particular horse had a vicious temperament and tried to kick and bite everyone in the vicinity. However, once the rider was in the saddle, the very same creature became an excellent show jumper and moved in complete accordance with the needs of the rider. After listening to this story, the students brainstormed possible reasons why such a horse that had obviously been highly trained could have become such a dangerous animal. The majority of students felt that because the horse was so responsive once the rider had mounted that he was not intrinsically evil, although could have been genetically predisposed to bad-temper. Most agreed that it was some extrinsic circumstance that had caused the horse to start behaving in that way. Students then operated on the premise that human beings are, likewise, not born evil, and worked in groups to come up with various possibilities of why the perpetrator of in a bullying situation had become a bully.

There were various strategies used to build context such as the brainstorming and the online research before the victim and "why the bully became a bully" tableau role plays. These latter role plays proved rather challenging for the students, to such an extent that class time ran out and the development of the role play was assigned as homework for the next class. In their final evaluations, students commented that throughout that weekend and into the next week, they had text-messaged and e-mailed the other students in their 
group, brainstorming and developing ideas for this role play. However, it was the struggle that they had to undergo which paradoxically allowed the students to engage with the process drama on a deeper and more affective level, as can been seen in the transcribed role play below:

Female Student 1:

Skipping across the room obviously delighted.

Dad, Dad! Hey look at this! I got very good marks in test, on this math exam. Male Student:

Staring sullenly with his back turned to her. Turns towards her, his inner rage against the world apparent to all.

Huh, what is this? I don't care about it. I don't care about you either.

He rips the exam paper in two.

Female Student 1:

This was not the anticipated response so she looks as if she is about to cry.

But Dad, I. .. I...

Male Student 1:

He loses his temper and lashes out.

Go away. You aren't my daughter.

He strikes her.

Female Student 1:

Caught off-guard, she cries out.

Ooh....

In pain, she stoops and picks up the ripped exam and leaves the room. On the street, she bumps into her friend.

Female Student 2:

In a very cheerful mood.

Hi! Listen, listen! I had a good score on the test.

Female Student 1 peers to look at the score of 70\%. She looks down at her own torn exam of $98 \%$.

So, my parents are going to take me to a Kobe restaurant - I will eat steak! How about you?

Female Student 1:

Female Student 1 looks down at her ripped exam, sullenly examining her score against the Female Student 2's score before looking up with a nasty smile and says in a threatening, low voice:

Why are you so smiling? Hey, do you really think this is the best?

Female Student 2:

Looking really hurt and confused.

It IS for me.

Female Student 1:

In a voice shaking in jealous rage.

Hey, why only you? My dad didn't admire me at all. Why only you?

She scornfully rips up FS2's exam. Her voice goes from quiet to screaming:

I hate you. You are so.... disgusting. I HATE YOU! 
To debrief from the emotional intensity which the two role play sessions had unleashed, students wrote 250-word paragraphs in both their roles as victim and bully. Writing-in-role helped deepen students' emotional engagement as well as provided a personal and reflective aspect, irrespective of the level of linguistic ability. Interestingly, self-reflection is a key feature from elementary school education and pervades Japanese society, so students were au fait with the concept and being in persona allowed them the freedom to write from the perspective of another. For online homework, students researched about the official incidences of bullying in the Japanese educational system and posted their findings online in the class discussion group.

The next day, the class was in-role for the event of the funeral. The stage was set by placing a long coat with a hat on a desk to symbolize the corpse and the students as a class group named the person who had committed suicide after being bullied. Each student decided on his or her relationship with the victim, and then came in single file to express their condolences with the family as well as to explain their relationship to the victim. There was a significant difference in the way in which the two classes coped with such a sad event. The first more academic class was somber and serious and the ceremony was conducted as a traditionally Christian funeral. The second class, dealt with the serious topic by injecting as much humor as possible about the shared madcap adventures that they had experienced with their dead friend. They extemporarily offered their own "gifts" as a final farewell, a feature of Buddhist graves and altars in Japan. Interesting, in the debriefing in diary, both sets of writing-in-role showed the depth of emotion that each student had experienced towards the event. Despite varying linguistic abilities, all students wrote clear, poignant and tragic accounts of the funeral and their function within it in paragraph format, which was submitted the following class. As a result, the following class commenced with optimism, and now that the dark and tragic sides of bullying had been explored, there was a keen sense that it was time to find the how bullying could best be prevented and avoided.

\subsection{And ... Action: Winding Down}

Students were, for the last time, assigned random groups to research for the final performance assignment online and in real-time. While the emphasis of process drama is on the process rather than the performance, the only stipulation set down by the English Department at KGU was that there would be a final performance to fulfill MEXT guidelines which are to demonstrate the students' abilities to give clear presentations and speeches as well as logically refute points through debate. For this final performance, the coordinator of the English Department within the Faculty of Human Welfare Studies, Dr. Yoko Nakano, attended the class in-role as president of KGU, to offer commentary on the students' work. As she also taught many of the students the compulsory courses in reading and writing, she was amazed to see the same students in a rather different capacity whereby they were active learners and able producers 
of English. She expressed her astonishment to the sounds of laughter and cheers from both her and the students and joked that she had never heard them speak English in her classes.

Her surprise was genuine, to the extent that she delivered a speech to the Executive Committee with a recommendation that the process-drama projects in English Communication continue. Her recommendation was approved.

\subsection{Roles and Strategies}

The roles that the students donned throughout the semester were manifold and included perspectives of the victim, the bully, the bully as victim and of the student council. These roles ranged from the five campaign organizers, the bullying perpetrators and their victims, classmates of the suicide victim, a priest, relatives, girlfriends and childhood friends. It was the role of the teacher to set the scene for each class and to guide the proceedings along smoothly, as well as to play devil's advocate in role as the local gossip deliberately defaming and slandering the victim and siding with the perpetrator of the bullying. Finally, the role of the president was to provide impetus and closure for the entire project. The thread that bound the students together on their exploration of bullying was the one that echoed their actual status as the first and only students of the HWS; therefore there was an onus on the students to work things out together as a peer group because there were no second, third or fourth year students who could support them. This sense of responsibility placed upon them by the president-in-role's initial request to launch a campaign against bullying and also the framework of the project in effect mirrored the one that they had to subscribe to on a daily basis in their roles as the first students of the HWS Faculty.

The presence of physical signs allowed for a deepening of understanding and also fostered the creativity necessary to make the imaginary leap into the situation of bullying. The president's initial letter was affixed to the blackboard throughout the semester, and the final letter by the students in role as the council was sent to the president to invite her to the final day of the process drama project. Even the presence of the long winter coat laid out as the corpse fueled the collective imagination of the two groups. Throughout the semester, there were video clips of anti-bullying campaigns from Australia, New Zealand and America, which provided stimulus for discussions on whether bullying was culturally dictated or universal to all societies. Students had lively discussions as to whether the same anti-bullying campaigns could be applied in the Japanese context. 


\section{Analysis}

The ongoing assessment of the course was conducted through writing-in-role, questionnaires, role plays and online research. To meet $\mathrm{MEXT}^{2}$ guidelines, there was a final student evaluation of the entire course in the form of an open letter to the teacher about the pros and cons of the project and a grade of $20 \%$ for the final anti-bullying campaign performance. This performance utilized some of the role plays that had been developed throughout the semester and it included a live debate in front of the coordinator in the role of the president of KGU. Other methods used to assess the students' development throughout the process drama were teacher observation and note taking, student peer evaluations and commentaries, online research findings posted in the class Google Group as well as photographic and digital recordings of the role plays.

Most students indicated that the process drama section of the course was conducive to communicating with other Japanese language speakers in the target language of English. Another benefit that the students reported on was the degree of comfort that the role play and other group work provided, while Google Group gave students a technological forum in which they could explore issues with others in English. One student commented, "Surely, we students have to teach each other," which could be interpreted as a willingness to help less able members of the class. Another student commented, "I usually took a positive attitude in this class. I gave priority to English over Japanese and talked. ...In addition, this class was given an opportunity when I thought about bullying so I had many discussions about bullying in English. I got new sense of value." The evaluations certainly echoed Bowell and Heap's (2001: 127) assertion that learners "find well-constructed drama engaging, exciting, moving, challenging, rewarding and hugely enjoyable" and seemed to be applicable to the cultural context of the university English language classroom of HWS.

This process drama research project was part of an empirical case study based on observation and experience of the elective course English Communication II. As Winston points out (2006: 45) “... we use case study to seek out rather than solve problems, provoke rather than answer questions, deepen our understanding rather than rushing to closure." In this pilot study, many interesting questions relating to bullying within the context of sport came forth. Students displayed enthusiasm when discussing the nature of bullying within sport- whether hazing within the sporting hierarchy could push an athlete to meet the best of his/her physical fitness or was hazing in sport morally wrong. Students showed a clear understanding that the lines between bully, victim and bystander are blurred, which captures the central question of Olweus' most recent work (2007: 441-465) "Bullies and victims at school: Are they the same pupils?"

\footnotetext{
${ }^{2}$ Ministry of Education, Culture, Sports, Science and Technology
} 


\section{Conclusion}

According to MEXT statistics, the issue of bullying decreases as the years progress, therefore high school and university were isolated as being the time in which bullying was least prevalent. In the case of these first year students in HWS, the highest incidences of bullying took place at the elementary school level and petered out completely at the university level. This is also in line with the findings of Smith et.al. (1999) and yet there may be one more possibility. The Christian discourse uniting the students of KGU and the zero-tolerance towards bullying could also have influenced the outcome.

However, the final evaluation assignments indicated that while students struggled with the theme of bullying, the style of the process drama reminded many of the learner-centered Japanese elementary school curriculum. This seems to have freed the students to the extent that everyone commented on the increasing psychological comfort when communicating in English. Another student asserted that he "could learn many things, especially about bullying. I thought it was good to focus on a social problem. We studied not only English but also about society's morals." Therefore, all students seemed to respond positively to the fusion of English language learning with a social theme and to the entire process drama project and campaigned for doing a similar-style project on another social issue the following semester.

Finally, through the feedback from both students' evaluations and that of the course coordinator, process drama as the vehicle for linking language acquisition with a social issue relevant to the core studies within the Faculty of Human Welfare Studies was accepted as the integral part of the English Communication Course. The topics for the remaining two semesters were chosen by the students and seemed to reflect the caring ethos HWS: the problems which immigrants face in Japan and the issue of homelessness. Throughout all the process drama projects, students not only gained the valuable skill of thinking critically in the L2 of English, but also developed their confidence in their usage of English. Furthermore, the use of process drama allowed the students a safety screen from which they could voice honest opinions in the guise of a role, which they might not otherwise be able to do. It is hoped that the HWS continues to raise students' social conscience in such a compelling way as process drama Bibliography

Bolton, Gavin (1984): Drama as Education: An argument for placing Drama at the centre of the curriculum. London: Longman Group Limited

Bowell, Pamela \& Heap, Brian (2001): Planning Process Drama. London: David Fulton

Doi, Takeo (1971): Amae no Kouzou / The Anatomy of Dependence. Tokyo: Toshisuke Koibuchi

Eslea, Mike; Menesinin, Ersilia; Morita, Yohji; O'Moore, Mona; Mora-Merchan, Joaquin A.; Pereira, Beatriz; Smith, Peter K. (2003): Friendship and 
Loneliness Among Bullies and Victims: Data from Seven Countries. In: Aggressive Behavior 30, 71-83

Heathcote, Dorothy (1984): Collected Writings on Education and Drama. Illinois: Northwestern University Press

Heathcote, Dorothy \& Bolton, Gavin (1996): Drama for Learning: Dorothy Heathcote's Mantle of the Expert Approach to Education. London: Greenwood

Kanetsuna, Tomoyuki; Smith, Peter K.; Morita, Yohji (2006): Coping With Bullying at School: Children's Recommended Strategies and Attitudes to School-Based Intervention in England and Japan. In: Aggressive Behavior 32, 570-580

Ministry of Education, Culture, Sports, Science and Technology (2007): National Statistics of Bullying Incidences by Prefecture. Retrieved on November 20 $\underline{\text { th }}$, 2009 from, http://www.e-stat.go.jp/SG1/estat/GL02020101.do? method=exte

Morita, Yohji; Soeda, Haruo; Soeda, Kumiko; Taki, Mitsuru (1999): Japan. In: Smith, Peter K. (eds.): The Nature of School Bullying: A Cross-national Perspective. London and NY: Routledge, 305- 323

Okano, Kaori \& Tsuchiya, Motonori (1999): Education in Contemporary Japan: Inequality and Diversity. Cambridge: Cambridge University Press

Olweus, Dan. (1977): Aggression and Peer Acceptance in Adolescent Boys: Two Short-Term Longitudinal Studies of Ratings. In: Child Development 48, 1301-1313

Slade, Peter (1954): Child Drama. London: University of London

Slade, Peter (1995): Child Play: Its Importance for Human Development. London: Jessica Kingsley

Smith, Peter; Morita, Yohji; Junger-Tas, Josine; Olweus, Dan; Catalano, Richard; Slee, Phillip (1999): The Nature of School Bullying: A Cross-National Perspective. London: Routledge

Solberg, Mona E.; Olweus, Dan; Endresen, Inger M. (2007): Bullies and Victims at school: Are they the same pupils? In: British Journal of Educational Psychology 77, 441- 464

Taki, Mitsuru (2001): Japanese Bullying: Ijime - A Survey Analysis and an Intervention Program in School. In National Institute for Educational Policy Research of Japan, Retrieved on November 28 ${ }^{\text {th }}$ from http:// www.nier.co.jp/a000110/Toronto/pdf 
Toman, Conrad (1980): From Sakoku to Kaikou - The Transformation of Foreign Policy Attitudes, 1853- 1868. In: Monumenta Nipponica 35 (1), $\underline{1-19}$

Tremi, Jacqueline Noel (2001): Bullying as a Social Malady in Contemporary Japan. In: International Social Work 44, 107-117

Tsuchida, Ineko \& Lewis, Catherine C. (1999): Responsibility and Learning: Some Preliminary Hypotheses about Japanese Elementary Classrooms. In: Rohlen, Thomas, P. \& Le Tendre, Gerald K. (eds.): Teaching and Learning in Japan. England: Cambridge University Press, 190-212

Wagner, Betty Jane (1976): Dorothy Heathcote: Drama as a Learning Medium. Washington DC: National Education Association

Way, Brian (1967): Development through Drama. London: Longman Books

Weltsek-Medina, Gustave (2007): Webpage Supplement to Chapter 9: Process Drama in Education: General Considerations. In: Blatner, Adam \& Wiener, Daniel J.: Interactive and Improvisation Drama: Varieties of Applied Theatre and Performance. Retrieved on December 5 ${ }^{\text {th }}, 2009$ from http://www. interactiveimprov.com/procdrmwb.html

Winston, Joe (2006): Researching through the Case Study. In: Ackryod, Judith (ed.) (2006): Research Methodologies for Drama Education. London: Trentham.

Yoneyama, Shoko (1999): The Japanese High School: Silence and Resistance. London: Routledge. 
A

Animated Anti-Bullying Poster, Japan

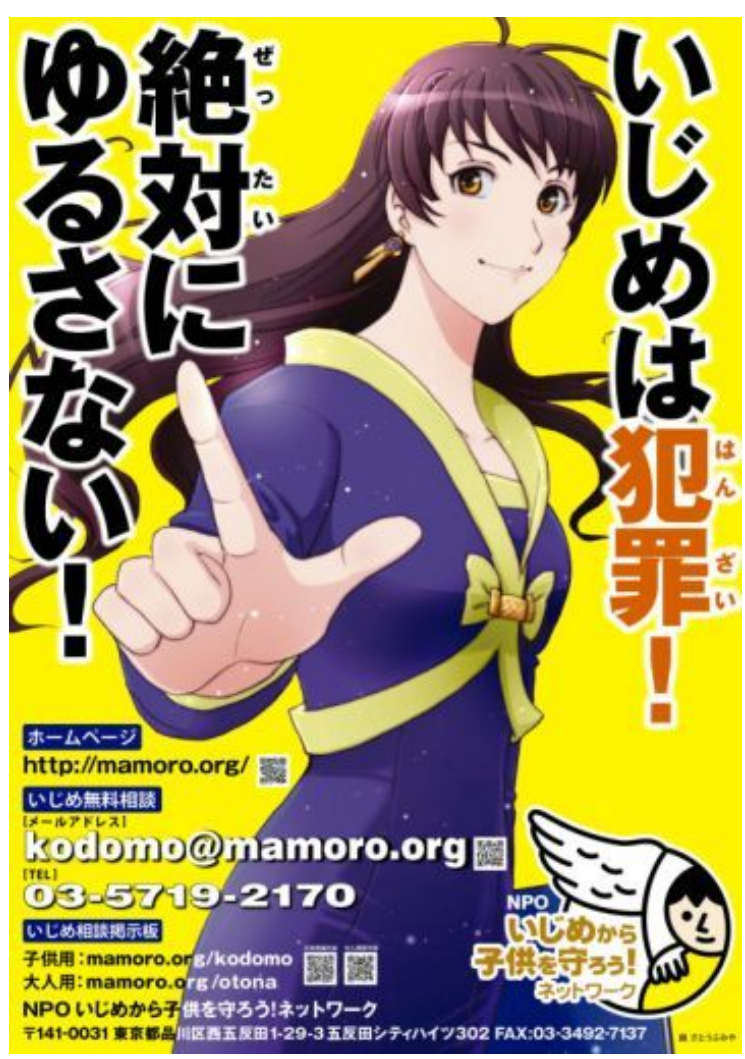


B

\section{Fall 2008, Sample Schedule}

\begin{tabular}{|c|c|c|c|}
\hline $\begin{array}{l}\text { Week } \\
9 \text { : Nov. } \\
27^{\text {th }} \text { \& } \\
\text { Dec. } \\
1^{\text {st }}\end{array}$ & $\begin{array}{l}\text { Process Drama } 1 \text { Negotiate } \\
\text { drama contract Starting and } \\
\text { stopping signals Introduction } \\
\text { to the theme and learning } \\
\text { area Brainstorm "what is a } \\
\text { bully" and "what is a victim" } \\
\text { Student activities: individual } \\
\text { to pair to group-work Make } \\
\text { a tableau of a situation. Use } \\
\text { one line of dialogue to } \\
\text { describe the thoughts and } \\
\text { feelings TIR as gossipy } \\
\text { student telling about what } \\
\text { happened last year in the } \\
\text { Law department Whole } \\
\text { university student meeting- } \\
\text { the issue of bullying Group } \\
\text { tableau Create and present } \\
\text { the tableau as a short } \\
\text { role-play (before, after, final } \\
\text { run-through) Assigning the } \\
\text { roles Drama-log \#1 Writing } \\
\text { Assignment \#1 }\end{array}$ & $\begin{array}{l}\text { Process Drama } 2 \text { Letter } \\
\text { from the president (TIR) } \\
\text { Drawing- in-role: who you } \\
\text { are and who you would like } \\
\text { to be Victim tableau and } \\
\text { thought-tracking } \\
\text { Photographs of the victim } \\
\text { tableau Teacher bullying the } \\
\text { victim with the "consensus" } \\
\text { of the group Photographs of } \\
\text { the bullying and consensus } \\
\text { Drama-log \#2 Writing in } \\
\text { role: the perspective of the } \\
\text { victim }\end{array}$ & $\begin{array}{l}\text { Prepare } \\
\text { Writing } \\
\text { Assignment \#1: } \\
\text { A reflection on } \\
\text { bullying (250 } \\
\text { words) Prepare } \\
\text { Writing } \\
\text { Assignment \#2: } \\
\text { The victim's } \\
\text { perspective } \\
\text { ( } 250 \text { words) }\end{array}$ \\
\hline
\end{tabular}


C

\section{The Science Experiment}

Takuya, Yuki, and $\mathrm{Mao}^{3}$ are working on a school science project growing crystals in a beaker. Each has been assigned a role, and Mao's job is to read the instructions out loud to the others. Unfortunately, Mao can't read. What's more, $\mathrm{s} /$ he is too embarrassed to admit it, so s/he fakes it by making up most of the instructions. Since the crystals have to be left overnight to grow, Mao has plenty of time to ponder what $\mathrm{s} /$ he's done. $\mathrm{S} /$ he knows that $\mathrm{s} /$ he has ruined the experiment. $\mathrm{S} /$ he is sure that they will all get bad grades. $\mathrm{S} /$ he is terrified that when the others find out what happened they will think s/he is stupid. The role play starts when Takuya, Yuki and Mao go to check on the experiment the next day.

${ }^{3}$ The names Yuki and Mao can be male or female within the Japanese context. 
D

\section{Online Homework (Screen Shot)}

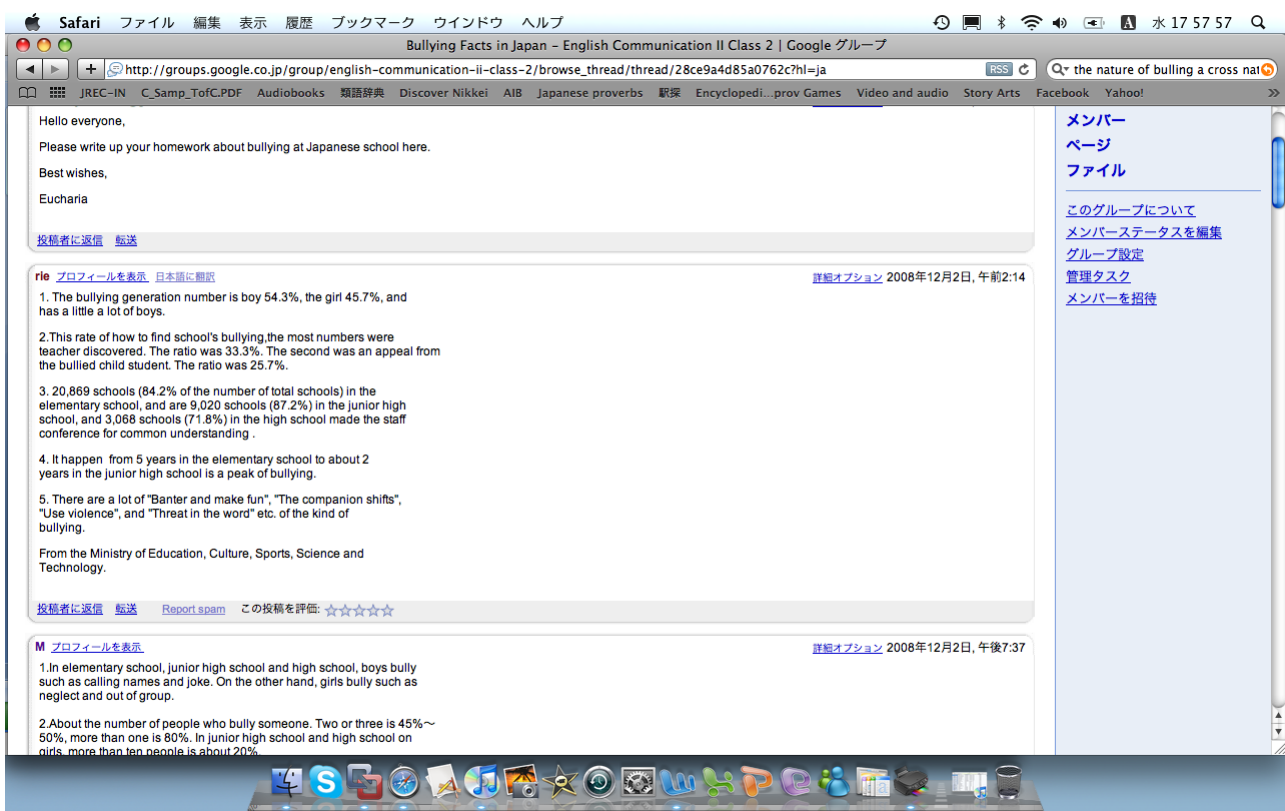


E

\section{Letter from the President}

The President,

Kwansei Gakuin University,

Uegahara Ichiban Chou 1-155,

Nishinomiya City,

Hyogo Prefecture,

662-0811

December 1, 2008

Dear Student Council,

It is with deep regret that I am writing this letter to you to ask for your help. Last week, on November $25^{\text {th }}$, a student from another faculty committed suicide. He was a very bright student; the entire teaching faculty thought him a wonderful student whose smile could light up a room. We are extremely worried and we would like to hear from you, the students about what could have been done to prevent this tragedy. Students are key to a successful Anti-Bullying campaign primarily because you usually know who the bullies are long before we, the adults do. Please find his final letter attached.

Yours sincerely,

The President 
$\mathbf{F}$

\section{Bullying Survey of HWS Students}

Taken from the Power Point presentation of International Association of Performing Languages, University of Victoria, Canada, March 6, 2009.

\subsection{Bullying Survey Results}

- Q.1. Have you ever been bullied?

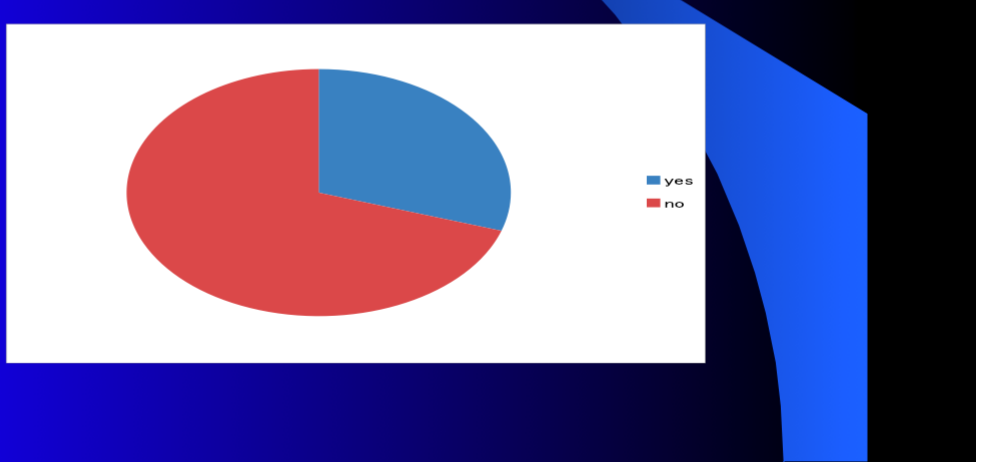


- How often?

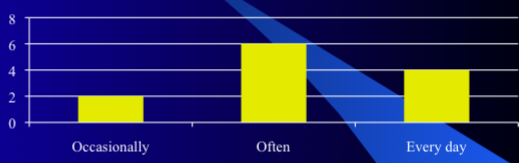

- Where?

Q.2. Have you seen other students being bullied at school?
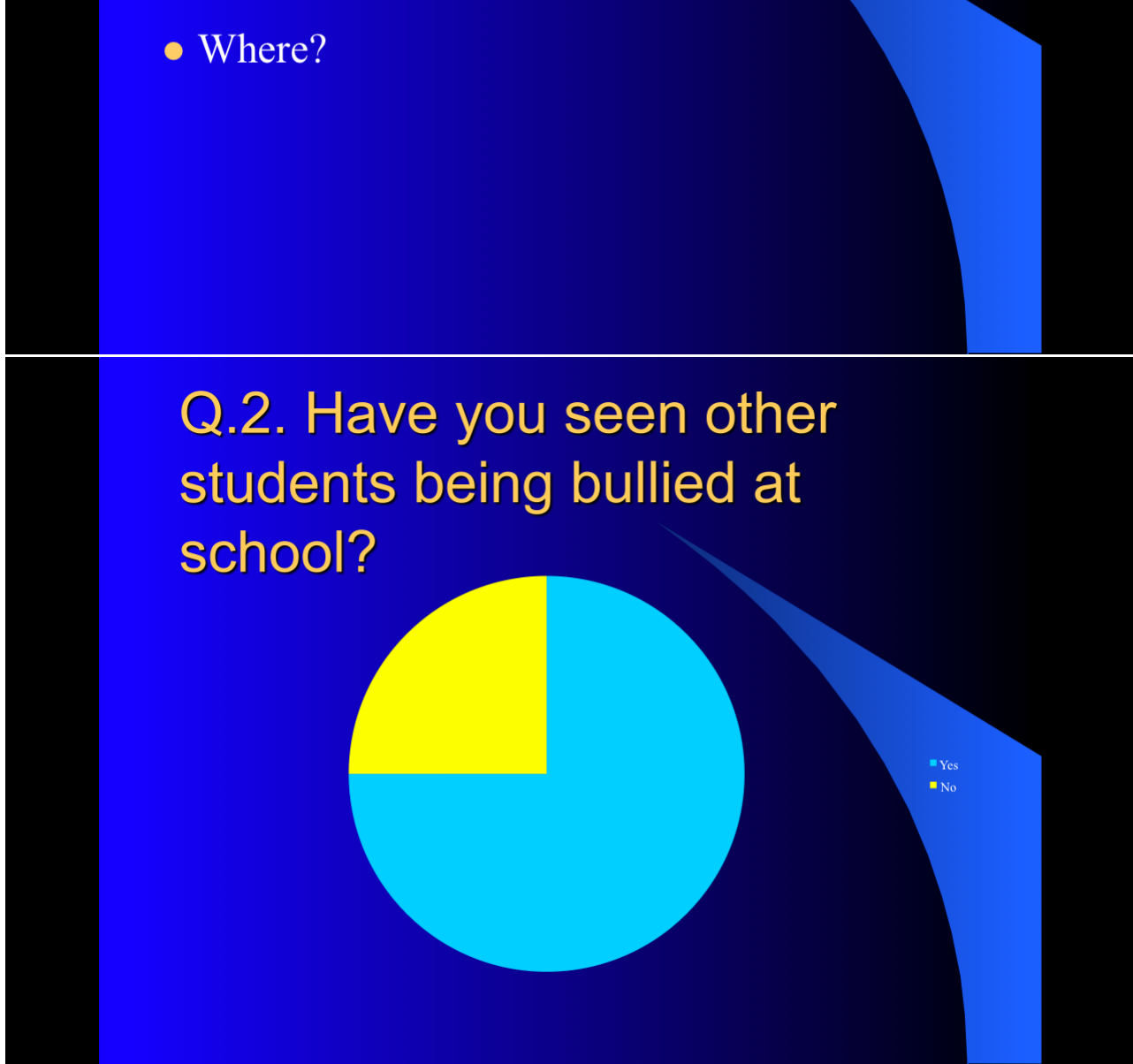

- How Often?
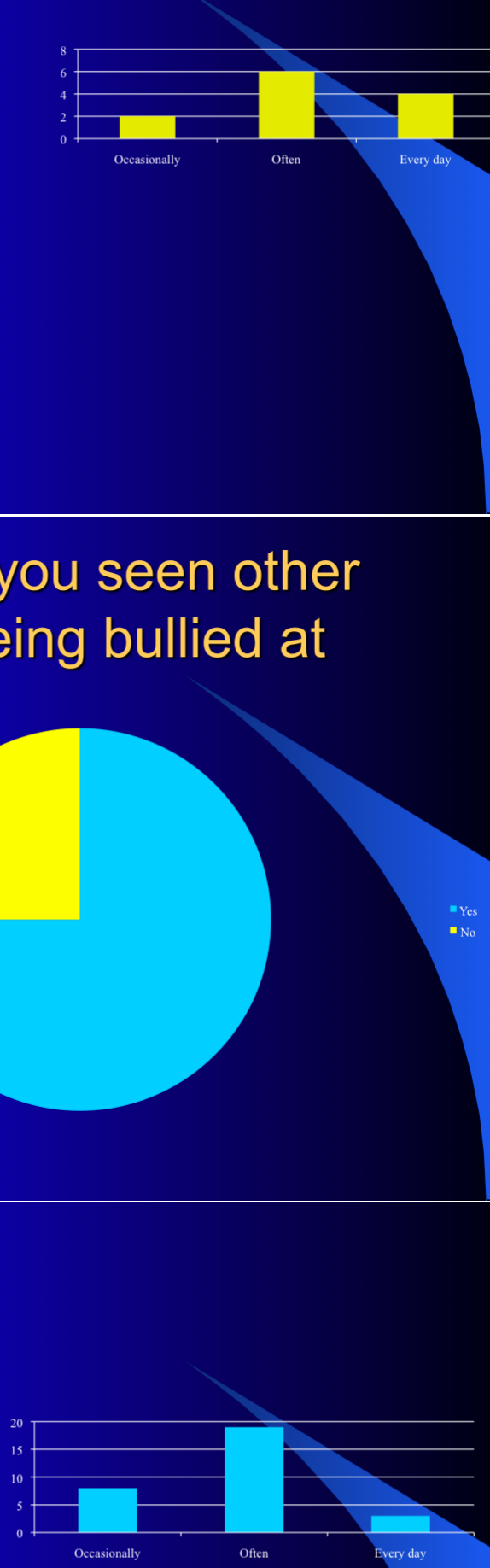

- Where?

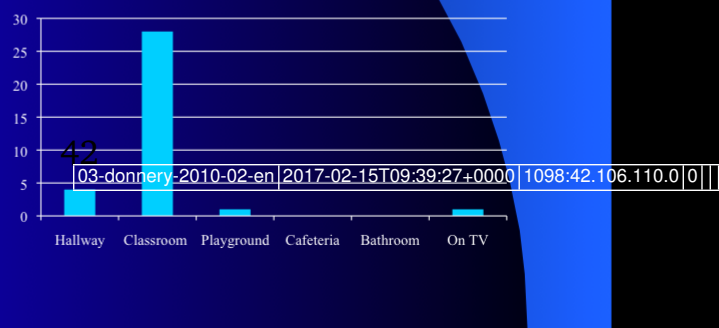

O 4 How much of a nrohlem was 
Q.7. How much of a problem is bullying for you now?

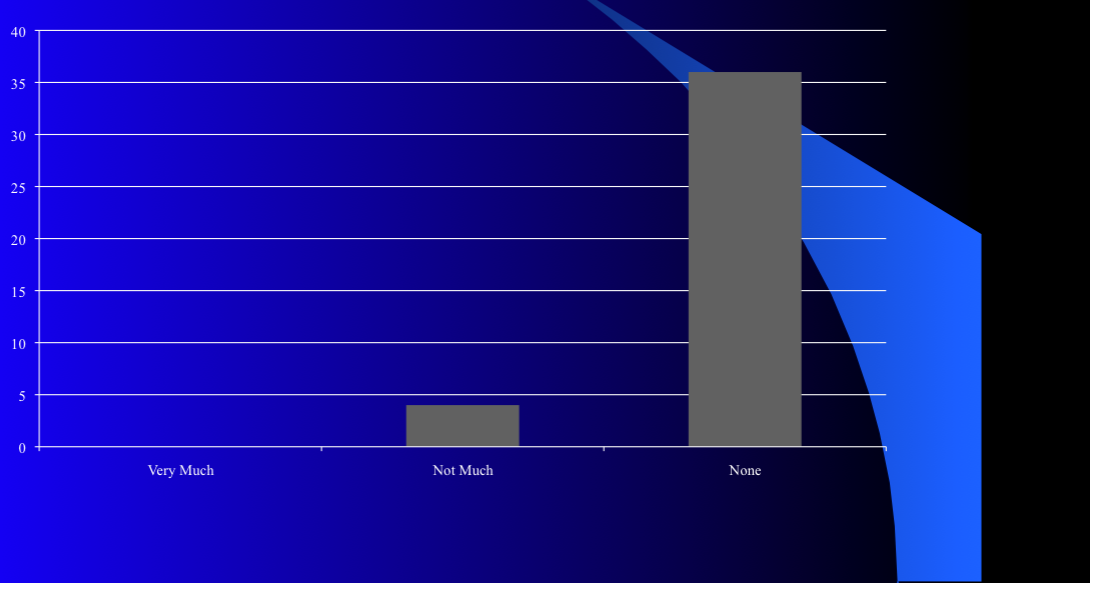

